\title{
The problem of rationing escape routes in pre-trial detention centers
}

\author{
Aleksandr Parfenenko ${ }^{*}$ and Artem Komrakov \\ Moscow State University of Civil Engineering, Yaroslavskoe shosse, 26, Moscow, 129337, Russia
}

\begin{abstract}
The article discusses the basic requirements for buildings and structures. The review of the scientific literature on fire safety revealed the lack of accounting for the working hours of pre-trial detention centers, as well as the influence of the employees of the institution. The existing risk assessment methodology is not applicable to such buildings, since the key factor in ensuring the safety of people is the time when the evacuation of people begins. The lack of standards and methods related to the risk assessment of buildings of pre-trial detention centers creates the need for large-scale experiments on the evacuation of people.
\end{abstract}

\section{Introduction}

Just two decades ago, Russian legislation adopted a series of documents that allow determining the fire safety of an object by calculating and assessing the risk.

According to the main documents, Federal Law № 184-FZ of December 27, 2002 "On Technical Regulation" and Federal Law No. 384-FZ of December 30, 2009 "Technical Regulations on the safety of buildings and Structures" put forward general requirements about the requirements for ensuring the safety of people in buildings and structures: during operation under normal conditions; in case of a threat of dangerous natural processes; in case of fire.

\section{Methodology}

The item related to ensuring the fire safety of the object is specified by Federal Law № 123-FZ of July 22, 2008 "Technical Regulations on fire safety requirements". According to [1] Article 6, the fire safety of an object is considered to be ensured in the case of full compliance with the fire safety requirements established by the technical regulations adopted in accordance with the Federal Law "On Technical Regulation" and regulatory documents on fire safety. However, if it is impossible to meet the requirements of regulatory documents, it is necessary to calculate the fire risks of the object, where the main value is $\mathrm{P}_{\ni, \mathrm{i}}$ the probability of evacuation of people. To determine this indicator, it is necessary to determine two values: the time it takes for people to completely leave the building, and the time of blocking traffic, in which independent evacuation of people is impossible. At the same time, the value of the first should not exceed the value of the second. This requirement is spelled out in article 53,

\footnotetext{
* Corresponding author: parf01@inbox.ru
} 
following which the safe evacuation of people from buildings in case of fire is considered secured, if the time interval from the time of fire detection to complete the process of evacuation of people to safe zone does not exceed the time required for evacuation of people in case of fire, which generally gives reasonable space-planning and constructive execution of the evacuation routes of the object of protection. The time interval from the moment of fire detection to the end of the process of evacuation of people to a safe area does not exceed the required time for evacuation of people in case of fire, which, as a rule, is achieved by reasonable space-planning and constructive execution of the evacuation routes of the object of protection.

The current of fire safety requirements, developed in accordance with article 89 [1] and set out in the document [3], which establishes requirements for evacuation routes and exits from buildings and structures, do not affect all buildings belonging to different classes of functional fire hazard. There are objects whose specific operating mode does not allow people to leave the building independently at the time of notification of a fire. One of the types of such facilities is a pre-trial detention center. One of the most important values that determines the fire safety of a building is the individual fire risk, the value of which should not exceed the established norm (it is different for each object).

\section{Results and discussion}

The existing set of rules offers to take jail for an object of class f 1.2. functional fire safety, and this means to consider the value of individual fire risk for the value of $2.81 * 10-2$ in accordance with the methodology [2], which is incorrect, as an achievement of this magnitude requires more of an emergency evacuation from the building of the jail, which is not possible for this type of institutions.

\section{Conclusions}

Currently, there are such documents for the design of a pre-trial detention centre, such as a joint venture $15-01$ - 2012 FEDERAL PENITENTIARY SERVICE OF RUSSIA; SP 247.1325800.2016; SP 308.1325800.2017. The main sections of these documents [4-6] are devoted to the design and construction of buildings. However, only a small part of the requirements is assigned to fire safety, which is not able to fully ensure the safety of the pre-trial detention center.

The specifics of the organization and detention of people in prisons do not allow prisoners to move freely around the facility; there is a requirement that directly indicates the need to create conditions for minimal movement around the facility, paragraph 8.2 [4]. Such requirements directly affect the safety of the people inside. Also there is the human factor in safety: according to the requirements of paragraph 7.2 of [4] only on-duty assistant chief of the detention facility during the evacuation of people the right to unlock the electronic door locks, cameras, containing in them.

Currently, there is no method of evacuation of people from the buildings of the pre-trial detention center. There is not a single known experiment to determine the time of evacuation of people, and this also means that the prison staff, most often, is not sufficiently aware of the measures and actions to remove people from the burning building. Complicating the situation is the fact that it is not possible to open all the doors of the cells of people and let them out, because there is no guarantee of a centralized exit from the building, because prisoners are able to harm both the staff and themselves (for example, in possible conflicts). In this case, an important factor is the psychophysiological state of people moving in the flow: in the domestic and foreign scientific literature [7-23], there is no description of any regularities of 
the flow movement consisting of such a contingent.

From this we can conclude that the calculation of risks for buildings of this type is not feasible in the current reality. It is necessary to develop a methodology for assessing the risk of buildings containing people of this type, or to supplement existing documents with the requirements for pre-trial detention facilities. However, before this, a series of large-scale experiments is needed to determine the time of evacuation of people from the building, as well as to determine the procedure for the actions of correctional institution employees to organize the rescue of people.

The fires that have occurred are a confirmation of the need for the fastest development of standards for ensuring fire safety of the pre-trial detention center.

So, for example, on 27.07.20 in the Moscow pre-trial detention center "Pechatniki" there was a fire on the first floor of the department. The fire occurred in the room containing sleeping accessories. Thick, dense smoke went to the 4th floor of the building where the people were located. The rescue of people from the burning building was complicated by the fact that 850 people were held in the pre-trial detention center, who did not evacuate at the time when the fire was already known. The delay in the start of the evacuation was solely a human factor. The staff of the detention center threw all their efforts to eliminate the fire, and not to save people (which is contrary to the primary actions on the fire).

On the night of February 10-11, a fire raged in the building of the Police department of of the Samara region (with a pre-trial detention center located inside). The fire, caused by faulty wiring on the second floor, where the documentation on the arrested persons was located, began to spread rapidly. The building of the regional Police department was too old and walls covered with numerous layers of paint, as well as places decorated plywood boards. It was quite warm outside, and the windows in almost all the offices were open, which provided additional traction for the fire. In a matter of minutes, the flames spread to the third floor and the corridors were filled with thick, acrid smoke. The slow evacuation process resulted in numerous casualties, not only among the prisoners, but also among the police.

Such situations are unacceptable, since the evacuation time should not exceed the time of blocking the tracks.

The importance of a well-thought-out systematic evacuation can be confirmed on the basis of computer simulations through the Pathfinder software. The authors of the article recreated a model (Fig. 1, 2) of the internal space of the pre-trial detention center building. In the model, several methods of evacuation of people were calculated, with the help of security personnel working in the institution. It was supposed to find out: how many people should be released from the detention cells and at what time interval, so that the evacuation would take as little time as possible. 


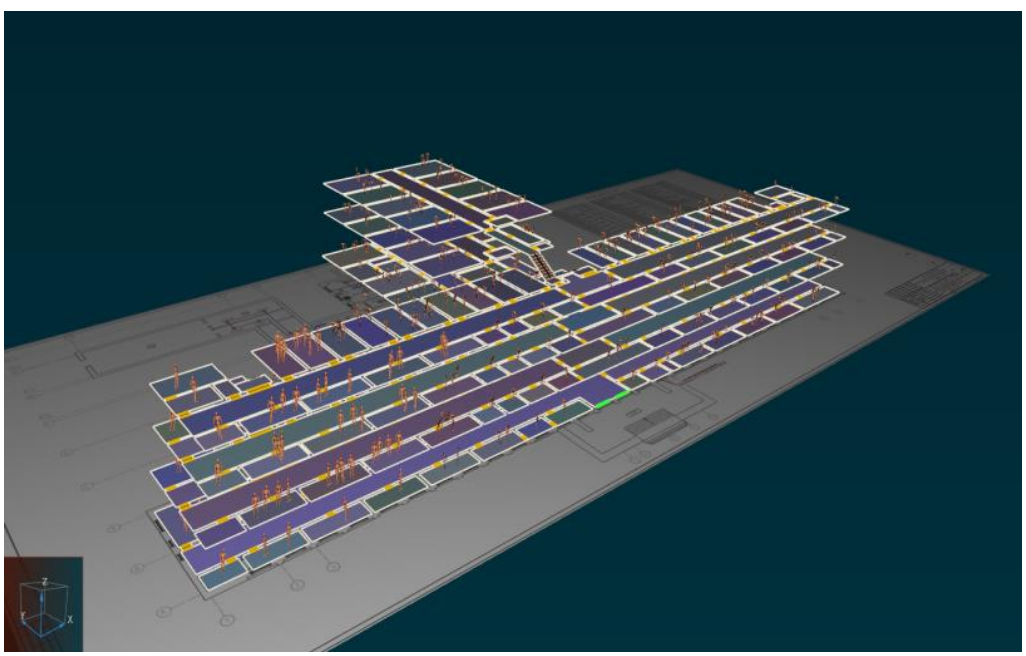

Fig. 1. Model of the building from the side

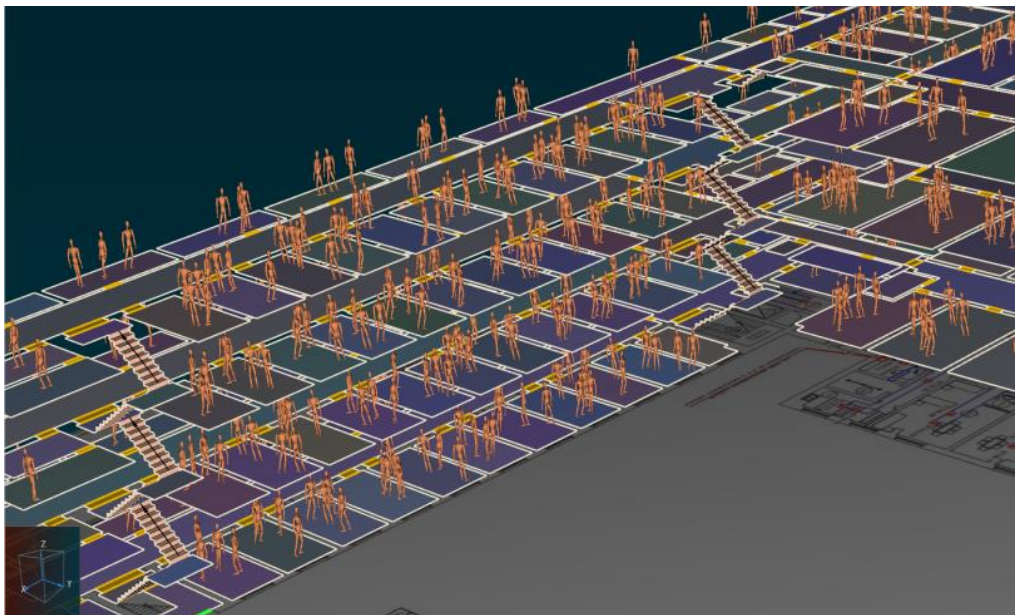

Fig. 2. Model of the building from the side

Based on the results of time measurements, it was found that for this object, it is most effective to release people from two cells in one wing of the building simultaneously with an interval of 10 seconds.

The graph in figures 3 and table 1 show the results of modeling the movement of human flows for 5 different evacuation scenarios. 


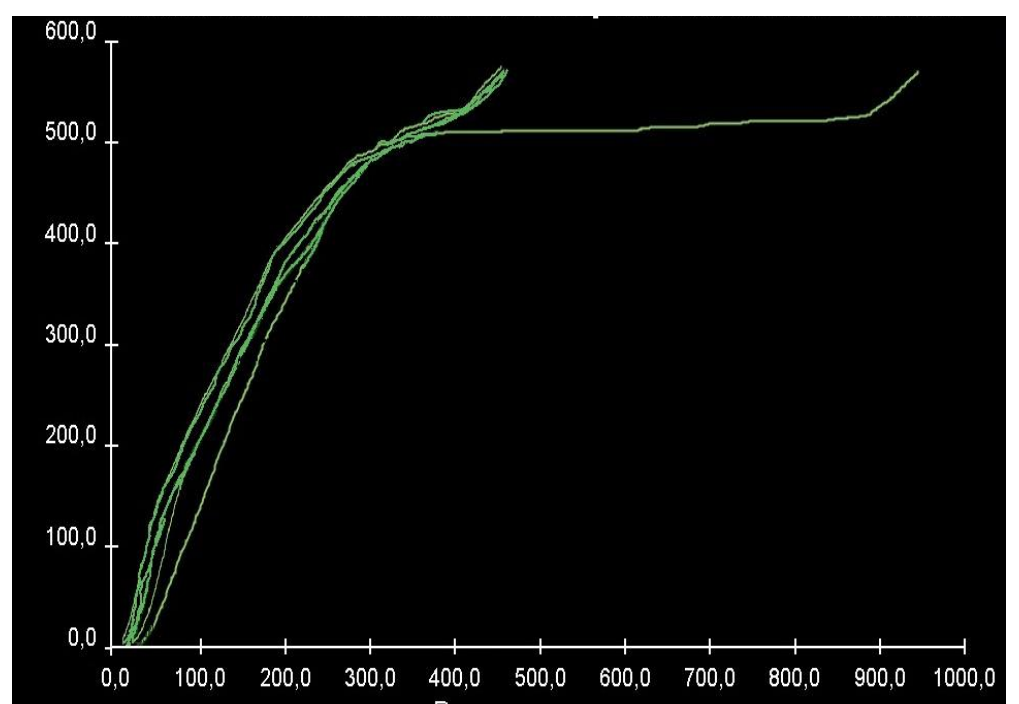

Fig. 3. The dependence of the number of people who left the building on the time in seconds.

Table 1. Dependence of the evacuation time on the number of security personnel involved.

\begin{tabular}{|c|c|}
\hline Number of security personnel & Evacuation time, sec \\
\hline 1 & 944 \\
\hline 2 & 424 \\
\hline 3 & 441 \\
\hline 4 & 453 \\
\hline 5 & 460 \\
\hline
\end{tabular}

The results of the simulation showed that the gradual evacuation of people from the building of the pre-trial detention center is able to prevent crowding and the formation of clusters on the stairwells. This principle of leaving the building is able to ensure the early evacuation of people and protect them from the effects of fire hazards. At the same time, the number of guards on duty on the floors plays a key role in ensuring the safety of people, influencing the parameter of the start time of evacuation when opening the doors in the cells. The optimal number of employees per 10 cells was 2 people, which reduced the evacuation time from 15.73 minutes to 7 minutes.

Currently, it is necessary to develop high-quality measures and requirements to ensure fire safety of buildings of pre-trial detention centers. The lack of research on the movement of human flows in pre-trial detention facilities does not allow for adequate rationing of escape routes, as well as predicting fire-hazardous situations at such facilities with further development of design standards.

\section{References}

1. Technical Regulations on fire safety requirements, taking into account the amendments made to Federal Law No. 117-FZ "On Amendments to the Federal Law Technical Regulations on Fire Safety Requirements":Law № 123-FZ of July 22, 2008.

2. Methodology for determining the calculated values of fire risk in buildings, structures and structures of various classes of functional fire hazard: appendix to the order of the EMERCOM of Russia of 30.06.2009 № 382, taking into account the changes approved by Order № 632 of the EMERCOM of the Russian Federation of 2.12.2015. 
3. SP 1.13130.2009 Fire protection systems. Evacuation routes and exits.

4. Design standards for Pre-trial Detention Facilities of the Federal Penitentiary Service SP 15 - 01 - 2012 Federal Penitentiary Service of Russia.

5. SP 247.1325800.2016 Pre-trial detention centers of the penitentiary system. Design rules.

6. SP 308.1325800.2017 Correctional institutions and centers of the penitentiary system. Design rules.

7. Parfyonenko A 2012 Rationing of fire safety requirements for evacuation routes and exits in the buildings of preschool educational institutions: Dis. Ph.D. (scientific adviser Kholshchevnikov V) Moscow AGPS of the Ministry of Emergencies of the Russian Federation (in Russian)

8. Kholshchevnikov V. V. Optimization of human traffic flow pathways. High-rise buildings: dis. M., 1969. -251 p.

9. Kholshchevnikov V. V. Research of human flows and methodology of rationing evacuation of people from buildings in case of fire. - Moscow: MIPB of the Ministry of Internal Affairs of the Russian Federation, 1999

10. Kholshchevnikov V 1999 The study of human flows and the methodology for standardizing the evacuation of people from buildings in case of fire Moscow MIPB of the Ministry of Internal Affairs of the Russian Federation (in Russian)

11. Alekseev Yu 1978 Formation and movement of human flows in the aisles of spectacular structures: Dis. Ph.D. 05.23.10 Moscow 254 p (in Russian)

12. Gvozdyakov V 1978 Patterns of movement of human flows in transport and communication facilities: Dis. Ph.D. 05.23.10 Moscow 211 p (in Russian)

13. Eremchenko M 1978 The movement of human flows in school buildings: Dis. Ph.D. 05.23.10 Moscow $186 \mathrm{p}$ (in Russian)

14. Kopylov V 1974 Research of parameters of the movement of people during forced evacuation: Dis. Ph.D. 05.23.10 Moscow 145 p (in Russian)

15. Predtechenskiy V. M. Human flows in buildings. - Moscow: Stroyizdat, 1983.

16. Larusdottir A. R., Dererichs A. S. Evacuation dynamics of children - walking speed, flow through doors in day care centers // Proceedings of the 5th International Conference on Pedestrian and Evacuation Dynamics/Gaithersburg (USA). - 2010. - Pp. 67-79.

17. Aydn O. A Qualitative Approach to Children of Developing Countries from Human Behavior Point of View // Proceedings of the 2nd International Symposium on Human Behaviour in Fire/Massachusetts (USA). - 2011. - Pp. 531-538.

18. Bruck D 2009 Community based research on the effectiveness of the home smoke alarm in waking up children Proceedings of the 4th International Symposium on Human Behaviour in Fire (Cambridge, UK) pp 335 - 344.

19. Dmitry Korolchenko, Tatiana Eremina, and Leonid Tanklevsky. Operation of cable lines under fire conditions. // E3S Web of Conferences 221, 02007, 2020, DOI: $10.1051 /$ e3sconf/202022102007

20. Dmitrii Korolchenko, Denis Minaylov, and Mikhail Eremin. Method of mathematical modeling for the experimental evaluation of fire retardant materials parameters. ERSME 2020, IOP Conference Series: Materials Science and Engineering, 1001, 012075, 2020. doi:10.1088/1757-899X/1001/1/012075

21. A A Komarov, N V Gromov and O N Korolchenko. Ensuring blast resistance of critically important buildings and constructions in case of air crash. IOP Conference Series: Materials Science and Engineering (MSE).

22. Eremina T., Korolchenko D., Kuznetsova I. The Study of the Complex of Properties of Water-Dispersion Fire Retardant Paint for Wooden Structures. Wood \& Fire Safety. WFS 2020. Springer, Cham. 2020. DOI: 10.1007/978-3-030-41235-7

23.Fedor Portnov and Daria Mikhaleva. Thermodynamic foundations of wood's operational properties. ITISE 2020. IOP Conference Series: Materials Science and Engineering 